\title{
AL-QUR'AN DAN MATERIAL GENETIK DALAM SEL KELAMIN PRIA PENENTU JENIS KELAMIN BAYI
}

\section{BayyinatulMuchtaromah}

Fakultas Sains dan Teknologi Universitas Islam Negeri (UIN) Malang, Jl. Gajayana 50 Malang 65144 Telp. (0341) 551354 Faks. (0341) 558882 Hp. 0811369317 e-mail: bayyinatul_uin@yahoo.co.id

\begin{abstract}
There are many main problems mentioned inside al-Qur'an which invites human being to believe. In many verses of al-Qur'an, men are called to pay their attentions to understand how they were created. Human creation and incredible aspects followed were strongly mentioned in many verses in detail until it's impossible for anyone who lived in the seventh century to recognize it. One of them was the information saying that the determinant of baby gender is the spermatozoa coming from men sperm. Allah said in his verse: "and that He (Allah) creates in pairs, male and female. From Nutfah (drops of semen male and female discharge) when it is emitted" (translation of al-Qur'an 53 verse 45-46)
\end{abstract}

Ulul Albab, Vol. 8 No. 2, 2007 
Branches of knowledge which have developed, such as Genetics and Molecular Biology, have proved scientifically the information accuracy which has been given by al-Qur'an. Nowadays it has been well-known that sex determination is determined by sperm of man and in fact women play no roles in this determination. If the ovum fuses with sperm which carries $Y$ chromosome than the baby will be born as a male. Confersely, if the sperm carries $\mathrm{X}$ chromosome than the baby will be a female. In the other word, the sex of the baby is determined by the kind of man's sperm chromosome which fuses with women's ovum.

Key words: sex, spermatozoa

\section{Pendahuluan}

Semua yang telah kita pelajari, memperlihatkan akan satu kenyataan pasti, al-Qur'an merupakan kitab berisi berita yang terbukti kebenarannya. Fakta-fakta ilmiah serta berita mengenai peristiwa masa depan, yang tidak mungkin dapat diketahui di masa itu, dinyatakan dalam ayat-ayatnya. Mustahil informasi ini dapat diketahui dengan penguasaan ilmu pengetahuan dan teknologi masa itu (abad $7 \mathrm{M}$ ). Ini merupakan bukti nyata bahwa alQur'an bukanlah perkataan manusia (Yahya, 2006) .

Al-Qur'an adalah kalam Allah Yang Maha Kuasa, Pencipta segala sesuatu dari ketiadaan. Dialah Tuhan yang ilmu-Nya meliputi segala sesuatu. Dalam sebuah ayat dalam al-Qur'an, Allah menyatakan:

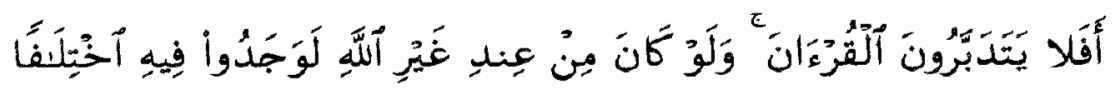

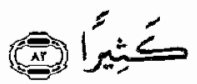

"Maka apakah mereka tidak memperhatikan al-Qur'an? Kalau kiranya al-Qur'an itu bukan dari sisi Allah, tentulah mereka mendapat pertentangan yang banyak di dalamnya." (QS, an Nisaa': 82). 
Disebutkan pula bahwa hanya orang yang diberi petunjuk dan rahmat saja yang memahami al-Qur'an, orang-orang yang tidak diberi petunjuk seperti ditutup telinganya dan seperti mendengar sayup-sayup dari jauh (Naufal, 1987).

Allah juga berjanji dalam kitab-Nya akan memelihara al-Qur'an yang telah diturunkan-Nya.

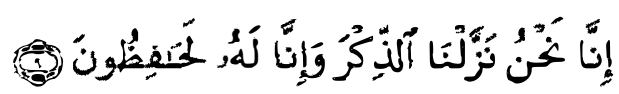

"Sesungguhnya Kami-lah yang menurunkan Al-Qur'an dan sesungguhnya Kami benar-benar memeliharanya." (QS. al Hijr: 9).

Tidak diragukan lagi bahwa al-Qur'an merupakan peletak dasar kemajuan Imu Pengetahuan dan teknologi. Namun tanpa kegiatan berpikir dan penelitian serius umat manusia tidak dapat menemukannya. Pada prakteknya kesadaran tersebut terwujud melalui kesadaran sikap. Hal ini tentu saja sangat relevan dengan karakteristik al-Qur'an yang senantiasa mengakhiri ayat-ayat sainsnya dengan kata sejenis:

Tidakkah kamu mengingat-ingat,

Tidakkah kamu berpikir,

Tidakkah kamu berakal.

Melihat hal tersebut, maka ilmu pengetahuan menduduki tempat pertama. Di sana ditemukan lafadz ilmu sebanyak $160 \mathrm{kali}$. Al-Qur'an yang terdiri dari 6236 ayat, 750 diantaranya berhubungan dengan alam dan ayatayat ilmiah. Sedangkan sisanya mencakup masalah syari'ah (hukum), mu'amalah, ibadah, akidah, tauhid, pemikiran dan kisah para nabi dan rasul terdahulu (Naufal, 1987).

Tidak sebuah kitab pun, kecuali al-Qur'an, yang memuliakan kedudukan ulama. Hal itu menunjukkan adanya perintah mengkaji berbagai ilmu (Terjemah Irsyadul Ibad, 1990).

Ulul Albab, Vol. 8 No. 2, 2007 
Perhatikanlah firman Allah di bawah ini:

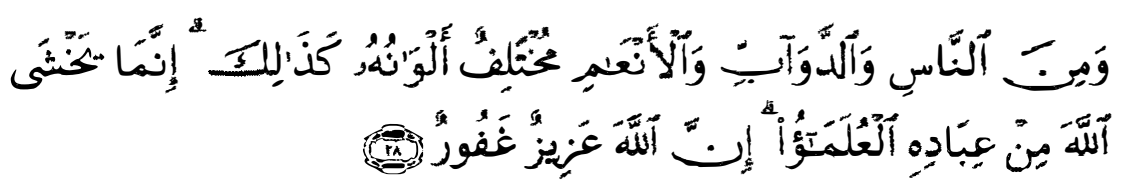

"......Sesungguhnya yang takut kepada Allah diantara hamba-hambaNya hanyalah ulama." (QS. Faathir: 28)

Dan Allah menjadikan mereka (para ulama) sebagai makhluk yang berkedudukan tinggi setelah malaikat, dalam masalah kesaksian keesaan Allah swt. Lihat dan perhatikan ayat berikut ini:

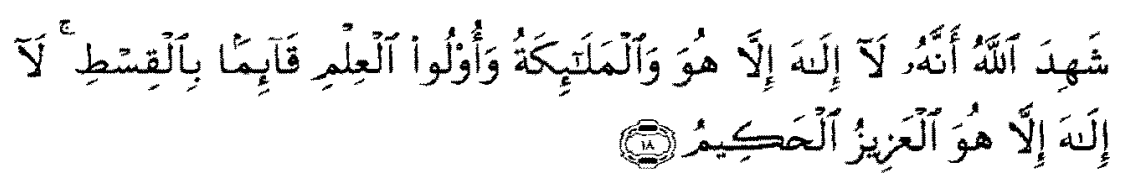

"Allah menyatakan bahwasanya tidak ada Tuhan melainkan Dia, Yang menegakkan keadilan. Para malaikat dan orang-orang berilmu (juga menyatakan demikian itu). Tak ada Tuhan melainkan Dia, Yang Maha Perkasa lagi Maha Bijaksana." (QS. Ali Imran: 18).

\section{Metode Kajian}

Penelitian ini dilakukan dengan mengkaji berbagai literatur baik dari jurnal terkini, teks book, artikel ilmiah serta informasi yang digali dari alQur'an, Hadist maupun sumber lain yang terintegrasi, kemudian dirangkum menjadi sutau kajian yang mendalam.

\section{Pembahasan:}

\section{Manusia tidak Diciptakan dari Air Mani yang Lengkap}

Orang-orang yang hidup di zaman modern ini pasti mengetahui, bahwa kelahiran berhubungan dengan air mani (semen) laki-laki yang diejakulasikan saat hubungan seksual. Fakta bahwa bayi lahir sesudah jangka waktu sembilan bulan tentu saja merupakan peristiwa yang gamblang dan tidak 
memerlukan penyelidikan lebih lanjut. Akan tetapi, sedikit infermasi yang dikutip di atas itu berada jauh di luar pengertian orang-orang yang hidup pada masa al-Qur'an diturunkan. Pengetahuan tersebut baru secara gamblang ditemukan oleh ilmu pengetahuan abad ke-20 (Yahya, 2006 b).

Saat hubungan seksual dan terjadi ejakulasi, sekitar 250 juta sperma dipancarkan oleh pria pada satu waktu. Sperma-sperma melakukan perjalanan 5 menit yang sulit di sepanjang saluran reproduksi si ibu sampai menuju ke tempat sel telur berada. Hanya seribu dari 250 juta sperma yang berhasil mencapai sel telur. Sel telur, yang berdiameter $120-180 \mu$, hanya memperkenankan satu sperma yang masuk. Segera setelah satu buah sperma masuk ke dalam sel telur, lapisan perivitelin sel telur akan mengadakan vitellin block, sehingga sperma lainnya tidak bisa masuk.

Artinya, untuk terjadinya individu baru bukan berasal dari air mani (semen) seluruhnya, tetapi bagian dari semen yaitu sel spermatozoa. Semen terdiri dari sel spermatozoa dan cairan seminal plasma yang berasal dari kelenjar assesori di sepanjang saluran reproduksi pria. Spermatozoa yang berjumlah ratusan juta tersebut akhirnya hanya satu yang akan membuahi sel telur (Yahya, 2006º).

Ini dijelaskan dalam al-Qur'an:

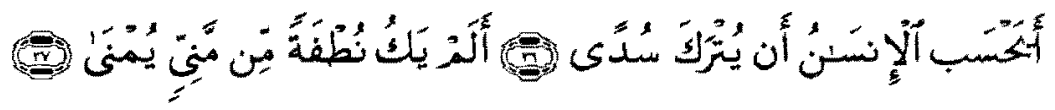

"Apakah manusia mengira akan dibiarkan tak terurus? Bukankah ia hanya setitik mani yang dipancarkan?" (QS.al Qiyaamah: 36-37).

Seperti yang telah kita ketahui, al-Qur'an memberi tahu kita bahwa manusia tidak terbuat dari mani selengkapnya, tetapi hanya bagian kecil darinya. Tekanan khusus dalam pernyataan ini mengumumkan suatu fakta yang baru ditemukan oleh ilmu pengetahuan modern merupakan bukti bahwa pernyataan tersebut berasal dari Ilahi.

Ulul Albab, Vol. 8 No. 2, 2007 
Dari keseluruhan sperma berjumlah sekitar 250 juta yang dipancarkan dari tubuh pria, hanya sedikit sekali yang berhasil mencapai sel telur. Sperma yang akan membuahi sel telur hanyalah satu dari seribu sperma yang mampu bertahan hidup. Kenyataan bahwa manusia tidak diciptakan dengan menggunakankeseluruhan air mani, tapi hanya sebagiankecil darinya, dinyatakan dalam Al-Qur'an dengan ungkapan, "setetes mại yang ditumpahkan" (Yahya, 2006 bc).

\section{Tinjauan Sistem Reproduksi Pria}

Pada pria sistem pembiakan atau reproduksi terdiri atas: (1) gonad berupa testis; (2) pembuluh atau saluran terdiri atas epididimis, vas deferens dan urethra (3) kelenjar tambahan terdiri atas prostat, vesikula seminalis, bulbouretralis dan littre (4) alat kelamin luar yaitu penis (Yatim, 1990).

\section{Testis}

Disebut juga buah pelir, berbentuk bulat lonjong, terdapat sepasang kiri-kanan dan tersimpan dalam suatu kantong yang disebutscrotum. Dalam tubulus dihasilkan spermatozoa, hormon inhibin, ABP (androgen binding protein) dan estrogen. Antara tubuli dalam tiap septa diisi oleh jaringan antara atau jaringan interstitial. Jaringan antara ini mengandung sel Leidig yang menghasilkan hormon testosteron.

\section{Epididimis}

Epididimis melekat ke satu sisi testis dari anterior ke posterior. Dari luar nampak seperti satu pembuluh besar berbentuk seperti huruf $S$ terbalik. Epididimis terbentuk atas 3 bagian yaitu (1) caput (2) corpus dan (3) cauda. Caput berada di bagian depan tempat bermuara vas eferens. Corpus adalah bagian tengah memanjang ke samping di sisi testis. Cauda ada di bagian ujung atau ekor, berbentuk huruf $U$, ujungnya bertemu dengan vas deferens. Epididimis berfungsi untuk (1) menyimpan (2) maturasi (3) reabsorbsi (4) sekresi dan (5) transportasi (Yatim, 1990). 
Suatuayat dalam Al-Qur'an surat Al-Mu'minun ayat 13 menunjukkan bahwa setetes air itu ditaruh di tempat yang tetap (Qarar) yang berarti organ reproduksi pria (epididimis dan salurannya).

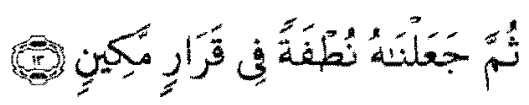

"Kemudian Kami jadikan saripati itu air mani (yang disimpan) dalam tempat yang kokoh."

\section{Vas Deferens}

Saluran ini terentang lurus, sepasang kiri-kanan, menyalurkan mani dari cauda epididimis ke urethra. Di saluran ini bermuara dua kelenjar mani besar yaitu vesikula seminalis dan prostat (Yatim, 1990).

Dalam al-Qur'an disebutkan mani itu merupakan cairan yang hina (Surat al-Mursalaat ayat 20).

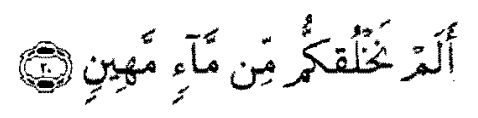

Artinya: "Bukankah Kami menciptakan kamu dari air yang hina."

Sifat "hina" (mahin) dapat diartikan, bukannya sifat cairan itu sendiri, akan tetapi karena hubungannya dengan fakta bahwa cairan itu dikeluarkan dari tempat keluarnya air kencing dan memakai saluran yang dilewati air kencing (Bucaille, 1979).

\section{Penis}

Penis atau zakar menyalurkan mani dalam genitalia wanita. Terdiri atas tiga bagian yaitu; (1) kulit (2) corpus cavernosum dan (3) urethra. Ketika ereksi darah yang dibawa arteri dialirkan ke rongga corpora hingga penuh, mekar dan tegang. Sedangkan vena tersumbat kontraksi otot dindingnya, sehingga darah tertumpuk dalam corpora.

Ulul Albab, Vol. 8 No. 2, 2007 
Bagian ujung penis berbentuk bongkol, disebut gland penis. Bagian ujung kulit yang menyalut gland penis dan lepas dari jaringan di bawahnya disebut preputium. Preputium inilah yang dipotong ketika khitan. Dengan terjadinya ereksi ini memungkinkan mani dipancarkan ke genitalia wanita.

Surat at Tariq ayat 6 menjelaskan peristiwa fisiologi reproduksi dalam proses penciptaan manusia. Manusia berasal dari air mani yang dipancarkan. Air mani tidak akan bisa memasuki genitalia wanita apabila tidak diejakulasikan atau dipancarkan. Ejakulasi dapat terjadi jika didahului dengan ereksi.

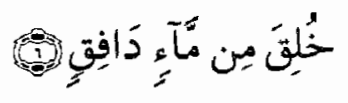

"Ia diciptakan dari air yang terpancar."

\section{Komposisi Semen (Air Mani)}

Semen atau air mani dalam Ilmu Reproduksi didefinisikan sebagai zat cair yang keluar dari saluran reproduksi pria saat terjadi kopulasi (hubungan seksual). Semen terdiri atas dua bagian yaitu sel spermatozoa dan cairan seminal plasma. Baik spermatozoa maupun cairan seminal plasma menurut analisis kimia terdiri atas rangkaian zat organik tertentu (Yahya, 2006 ${ }^{\mathrm{b}}$ ).

\section{Sel Spermatozoa}

Spermatogenesis merupakan proses pembentukan, pembelahan dan pematangan sel-sel gamet sampai menjadi sel gamet (sel kelamin) yang siap berperan dalam proses reproduksi. Pada pria proses spermatogenesis meliputi spermatositogenesis dan spermiogenesis sedang pada wanita disebut oogenesis. 


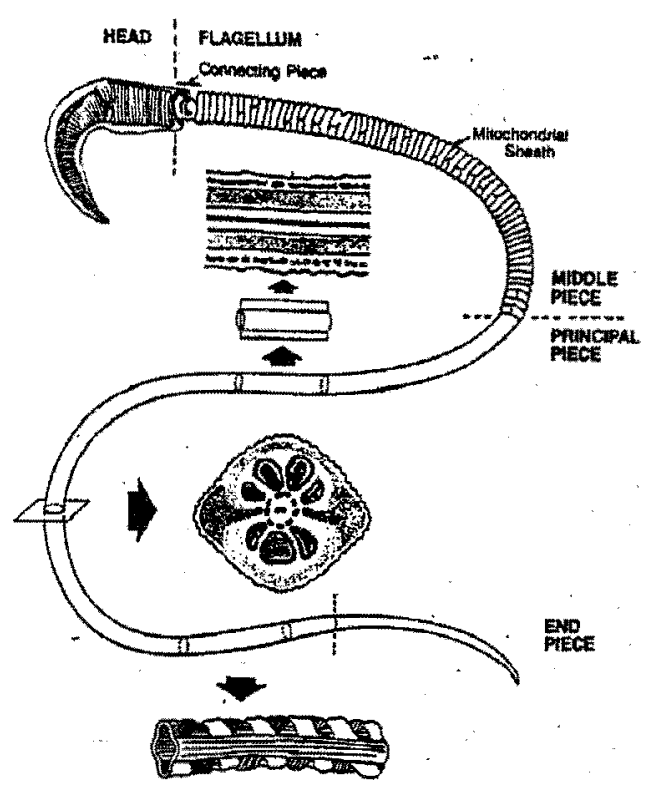

Gambar 1. Spermatozoa mamalia. Pada kepala terdapat akrosom yang melekat pada connecting piece dari flagela (ekor). Secara anatomis ekor dibagi menjadi 4 bagian yaitu: connecting piece, middle piece, principle piece dan end piece (Yanagimachi, 1994).

Pembentukan spermatozoa pada pria normal berlangsung terus sampai usia lanjut. Hal ini dimungkinkan selama spermatogonium induk (bakal sperma) masih tersedia. Spermatogenesis terjadi dalam tubuli seminiferi. Menurut Cormack dalam bukunya Clinically Integrated Histology bahwa perkembangan epitel seminiferi dalam pembentukan spermatozoa melalui 6 tahap dan terjadi dalam 64-74 hari.

\section{Cairan Seminal Plasma}

Cairan seminal plasma merupakan sekret kelenjar tambahan saluran reproduksi pria yang sebenarnya tidak dikeluarkan sekaligus waktu ejakulasi tetapi secara bertahap. Bila semen dibagi menjadi (3) porsi menurut urutan keluarnya, maka porsi I adalah hasil sekresi kelenjar bulbourethra dan kelenjar uretra, porsi II hasil sekresi kelenjar prostat dan biasanya porsi ini

Ulul Albab, Vol. 8 No. 2, 2007 
mengandung spermatozoa paling banyak yang berasal dari ampula dan epididimis. Porsi III yang paling banyak mengandung cairan berasal dari vesikula seminalis (Suhadi, 1978; Purwaningsih, 1997).

Plasma sperma berfungsi sebagai medium untuk transportasi spermatozoa dari saluran reproduksi pria menuju saluran reproduksi wanita, merupakan suatu buffer yang berisi makanan untuk spermatozoa, menetralkan asam di bagian distal saluran reproduksi pria dan pintu masuk rahim, dan melicinkan lingkungan agar memudahkan pergerakan sperma (Purwaningsih, 1997).

Hal yang dijelaskan berdasarkan sains modern di atas ternyata telah disebutkan dalam al-Qur'an bahwa cairan yang disebut air mani atau semen tidak mengandung sperma saja. Cairan ini justru tersusun dari campuran berbagai komponen yang berlainan (Yahya, 2006 ${ }^{\mathrm{a}}$.

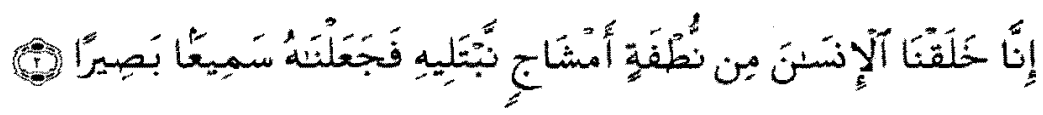

"Sungguh, Kami ciptakan manusia dari setetes mani yang bercampur, lalu Kami beri dia (anugerah) pendengaran dan penglihatan." (QS, al-Insaan:2)

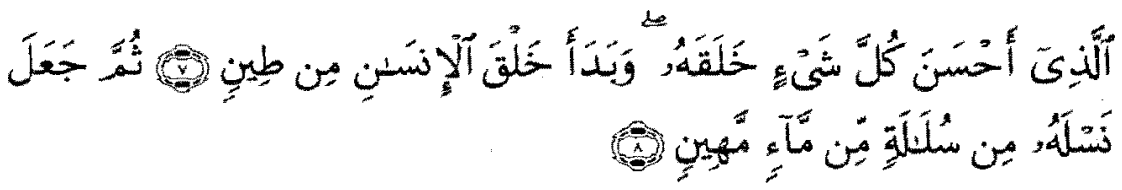

"Dialah Yang menciptakan segalanya dengan sebaik-baiknya, Dia mulai menciptakan manusia dari tanah liat. Kemudian Ia menjadikan keturunannya dari sari air yang hina." (QS, as-Sajdah :7-8)

Kata Arab "sulala", yang diterjemahkan sebagai "sari", berarti bagian yang mendasar atau terbaik dari sesuatu. Dengan kata lain, ini berarti "bagian dari suatu kesatuan". Ini menunjukkan bahwa al-Qur'an merupakan firman dari Yang Berkehendak dan Yang Mengetahui penciptaan manusia hingga serinci-rincinya.

Ulul Albab, Vol. 8 No. 2, 2007 


\section{Penentuan Jenis Kelamin pada Manusia Kromosom}

Dalam sel yang sedang membelah, kromosom biasanya dapat dilihat dengan menggunakan mikroskop biasa. Akan tetapi untuk mempelajari strukturnya, harus menggunakan sebuah mikroskop elektron, karena dapat memberikan pembesaran jauh lebih kuat. Salah satu bagian dari kromosom disebut sentromer, yaitu bagian yang membagi kromosom menjadi dua lengan (Suryo, 1998).

Kromosom dibedakan atas autosom (kromosom tubuh) dan kromosom kelamin (kromosom seks). Manusia memiliki 46 kromosom, terdiri dari 44 autosom dan 2 kromosom kelamin (Suryo, 1998).

\section{Pembelahan Sel Mitosis}

Gamet (sel kelamin) betina setelah dibuahi oleh gamet (sel kelamin) jantan akan bersifat diploid ( $2 \mathrm{n}$ ) dan dinamakan zigot. Dalam perkembangannya, zigot ini akan membelah berkali-kali dan proses pembelahan ini dinamakan mitosis (Yatim, 1987).

Mitosis berlangsung dalam beberapa fase, ialah interfase, profase, metafase, anafase dan telofase. (a) Interfase. Sel siap untukmulai membelah, tetapi belum memperlihatkan kegiatan membelah. Inti sel nampak keruh, lambat laun nampak benang-benang kromatin yang halus. (b) Profase. Benang-benang kromatin makin menjadi pendek, sehingga menjadi tebal. Terben-tuklah kromosom-kromosom. Tiap kromosom lalu membelah memanjang dan anakan kromosom ini dinamakan kromatid. Dinding inti mulai meng-hilang. Sentriol (bentuk seperti bintang dalam sitoplasma) juga membelah. (c) Metafase. Kromosom-kromosommenempatkan diri di bidang tengah darisel. (d) Anafase. Sentromer membelah dankedua buah kromatid me-misahkan diri dan bergerak menuju ke kutub sel yang berlawanan. (e) Telofase. Di tiap kutubsel terbentuk pasangan kromosom yang identik. Serabut gelen-dong inti lenyap dan dinding inti terbentuk lagi. Kemudian plasma sel terbagi menjadi 2 bagian, proses ini disebut sitokinesis (Yatim, 1987).

Ulul Albab, Vol. 8 No. 2, 2007 


\section{Meiosis}

Reproduksi seksual mencakup pembentukan gamet-gamet (gametogenesis) dan pembuahannya (fertilisasi). Gametogenesis berlangsung di dalam alat reproduksi. Gamet bersifat haploid (n) tetapi berasal dari sebuah sel induk yang diploid $(2 n)$. Berhubung dengan itu pembentukan gamet harus didahului dengan pembelahan reduksi dari jumlah kromosom dan pembelahan ini lazim disebut meiosis (Suryo, 1998). Berbeda dengan mitosis, meiosis ini berlangsung dalam 2 tingkat yaitu:

Meiosis I yang dibedakan atas beberapa fase, yaitu:

\section{Profase I}

Ini berbeda dari profase pada mitosis, yaitu bahwa kromosom-kromosom homolog membentuk pasangan yang dinamakan bivalen.

\section{Metafase I}

Pasangan-pasangan kromosom homolog menempatkan diri di bidang tengah dari sel secara acak.

\section{Anafase 1}

Sentromer belum membelah. Kini kromosom-kromosom homolog (masing-masing terdiri dari 2 kromatid) saling memisahkan diri dan bergerak menuju ke kutub sel yang berlawanan. Berarti jumlah kromosom telah diparuh dari keadaan diploid (2n) menjadi haploid (n)

Meiosis II, dibedakan atas beberapa fase: (a) Profase II. Serabut-serabut gelendong terbentuk lagi. (b) Metafase II. Sentromer-sentromer menempatkan diri di tengah sel. (c) Anafase II. Sentromer dari tiap kromosom membelah, kromatid-kromatid memisahkan diri dan bergerak ke kutub yang berlawanan dan merupakan kromosom. (d) Telofase II. Berlangsunglah sitokinese lagi, diikuti dengan terbentuknya dinding inti. Jadi pada meiosis, maka sebuah sel induk diploid akhirnya menghasilkan empat sel anakan masing-masing haploid. 


\section{Fertilisasi}

Persatuan antara gamet jantan (sperma) dan gamet betina (ovum) disebut fertilisasi. Sel telur (bersifat haploid) yang dibuahi oleh sel sperma (bersifat haploid) (Gambar 2) melebur jadisatu dan berkembang menjadi zigot (bersifat diploid) (Gambar 3) dan kemudian berkembang terus melalui mitosis (pembelahan) berkali-kali menjadi janin (embrio) (Gambar 3), bayi dan kemudian dilahirkan sebagai individu baru.

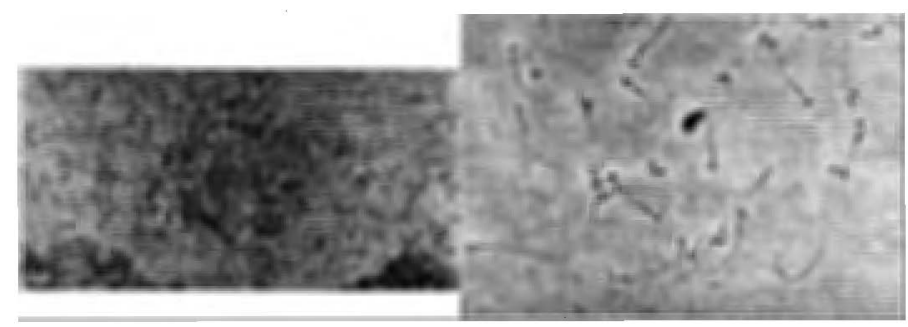

Gambar 2. Sel telur masak yang siap dibuahi sperma (www3. fertilethoughts.com / forums/v).

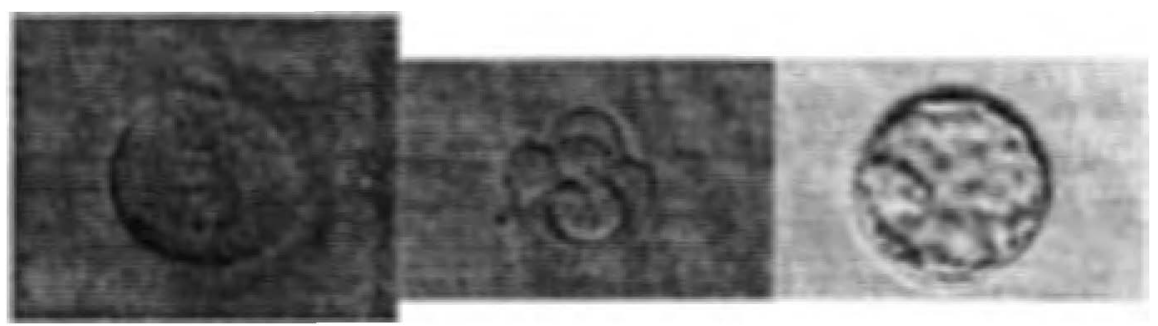

Gambar 3. Pronukleus jantan dan pronukleus betina bergabung dalam peristiwa fertilisasi kemudian membentuk zigot dan mengalami pembelahan (www3. fertilethoughts.com/forums/v).

Di dalam al-Qur'an Allah menyinggung peristiwa pembelahan mitosis, meiosis maupun fertilisasi dalam beberapa ayat-Nya. Ayat 189 dari Surat al A'raf telah menetapkan bahwa setiap yang diciptakan Allah berasal dari satu diri dan dari situ diciptakan pula pasangannya .

Ulul Albab, Vol. 8 No. 2, 2007 


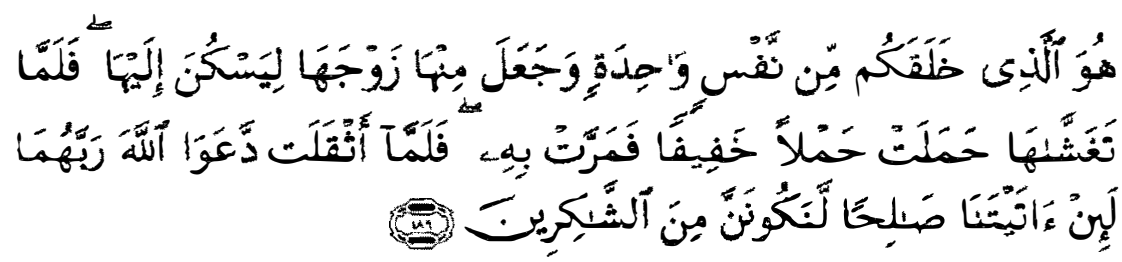

"Dialah Allah yang menciptakan kalian dari diri yang satu dan dari padanya Dia menciptakan pasangannya agar dia merasa tenang kepadanya." (QS. al-A'raaf:189).

Sedangkan pewarisan karakteristik seseorang kita ketahui saat ini secara kuantitatif separoh berasal dari ayah (sperma) dan separuhnya lagi berasal dari ibunya (sel telur). Perhatikan firman Allah dalam surat Maryam: 28.

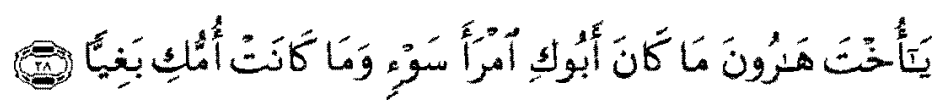

"Hai saudara perempuan Harun, ayahmu sekali-kali bukanlah seorang yang jahat dan ibumu sekali-kali bukanlah seorang pezina."

Maksud dalam ayat tersebut adalah bahwa Maryam tidak akan berbuat salah atau dosa, sebab ayah dan ibunya tidak mewariskan itu kepadanya, artinya bahwa sifat dan karakter Maryam merupakan warisan dari ayah dan ibunya.

\section{Tipe XY}

Inti sel tubuh manusia mengandung 46 buah kromosom,terdiri dari 44 atau 22 pasang autosom dan 2 atau sepasang kromosom kelamin.

Seorang perempuan memiliki 22 pasang autosom dan satu pasang kromosom X, sehingga formula kromosom untuk seorang perempuan adalah 22AAXX. Seorang laki-laki memiliki 22 pasang autosom +1 kromosom-X +1 kromosom-Y, maka formula kromosom untuk seorang laki-laki ialah 22AAXY. 
Seorang perempuan menghasilkan sebuah sel telur (ovum) yang bersifat haploid, ovum mengandung 22 autosom dan sebuah kromosom $\mathrm{X}$ (22AX). Sedangkan laki-laki membentuk dua macam spermatozoa yaitu:

a. Spermatozoa yang memiliki 22 autosom dan sebuah kromosom-X (22AX) yang dinamakan ginospermium.

b. Spermatozoa yang memiliki 22 autosom dan sebuah kromosom-Y (22AY) yang dinamakan androspermium

Apabila sebuah sel telur dibuahi oleh sebuah ginospermium, terjadilah anak perempuan. Tetapi bila yang membuahi androspermium terjadilah anak laki-laki,

Di dalam al-Qur'an ternyata telah dijelaskan jauh sebelum ilmu genetika modern berkembang bahwa penentu jenis kelamin bayi adalah spermatozoa yang berasal dari air mani laki-laki.

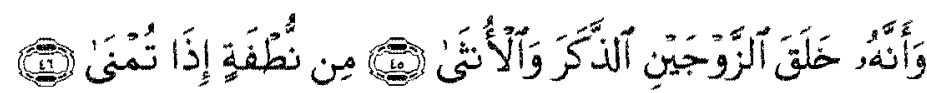

"Dialah yang menciptakan berpasang-pasangan pria dan wanita, dari air mani apabila dipancarkan" (QS. an-Najm: 45-46).

\section{Apakah Wanita Tidak Mempunyai Peranan Dalam Menentukan Jenis Kelamin?}

Sebuah penelitian dilakukan dengan meletakkan sperma pada cairan vagina dengan variasi kondisi asam dan kondisi basa disesuaikan seperti keadaan organ reproduksi wanita. Hasil penelitian tersebut menunjukkan bahwa sperma $\mathrm{X}$ lebih tahan terhadap kondisi asam, dan sperma $\mathrm{Y}$ akan mempunyai motilitas yang bagus pada kondisi basa (alkalin). Kondisi asam bisa saja membunuh kedua jenis sperma, akan tetapi pengaruhnya lebih berat pada sperma Y. Sperma X tidak saja mampu bertahan pada kondisi asam, tetapi juga mampu bertahan pada kondisi kurang menguntungkan

Ulul Albab, Vol. 8 No. 2, 2007 
seperti panas dan bahan kimia yang mengandung racun (Shettles and Rovink, 2006).

Dari hasil penelizian di atas dapat diketahui bahwa kondisi asam basa (lingkungan) organ reproduksi wanita ikut menentukan jenis kelamin yang dihasilkan pada saat pembuahan. Pengaturan waktu saat berhubungan badan menjadi penting untuk dilakukan jika menginginkan bayi dengan jenis kelamin tertentu.

Di dalam al-Quran Surat al-Baqarah ayat 223, wanita diibaratkan sebagai tanah tempat menebar benih untuk bercocok tanam sehingga kondisi tanah ikut menentukan terhadap tumbuhnya benih.

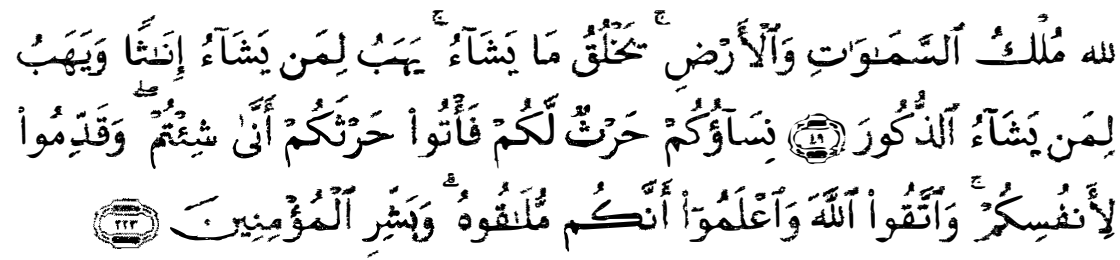

"Isteri-isterimu adalah (seperti) tanah tempat kamu bercocok tanam, maka datangilah tanah tempat bercocok-tanammu itu bagaimana saja kamu kehendaki. dan kerjakanlah (amal yang baik) untuk dirimu, dan bertakwalah kepada Allah dan Ketahuilah bahwa kamu kelak akan menemui-Nya. dan berilah kabar gembira orang-orang yang beriman."

\section{Menentukan Waktu Ovulasi}

Sebelum kita mempelajari teknik menentukan waktu ovulasi terlebih dahulu kita mempelajari siklus menstruasi. Siklus ini dimulai saat hari pertama pendarahan. Pendarahan biasanya berlangsung 3-7 hari, siklus ini bisa berubah-ubah dan pada tiap wanita tidaklah sama. Pendarahan terjadi karena luruhnya dinding rahim bagian dalam (endometrium). Menstruasi ini terjadi setiap bulan pada wanita yang normal. Wanita yang hamil tidak mengalami menstruasi.

Panjang siklus bervariasi dari 23 hari atau kurang untuk siklus pendek dan lebih dari 35 hari untuk siklus yang panjang. Ada sejumlah perempuan yang siklusnya teratur, sementara ada pula yang bervariasi sampai dengan 7 
hari. Untuk lebih memudahkan pemahaman, pada tulisan ini kita gunakan rata-rata siklus 28 hari.

Siklus menstruasi dibawah kontrol hormon seks. Untuk memudahkan, siklus ini dibagi dalam 2 fase, yaitu fase sebelum ovulasi dan fase setelah ovulasi. Siklus Menstruasi itu berbeda dengan Masa menstruasi.

Di dalam al-Qur'an pun telah diungkap mengenai menstruasi dan larangan untuk berhubungan badan pada saat itu karena kondisi dinding rahim (endometrium) sedang luka dan sangat rentan terhadap infeksi bakteri (www.Al-Firdaus. Com).

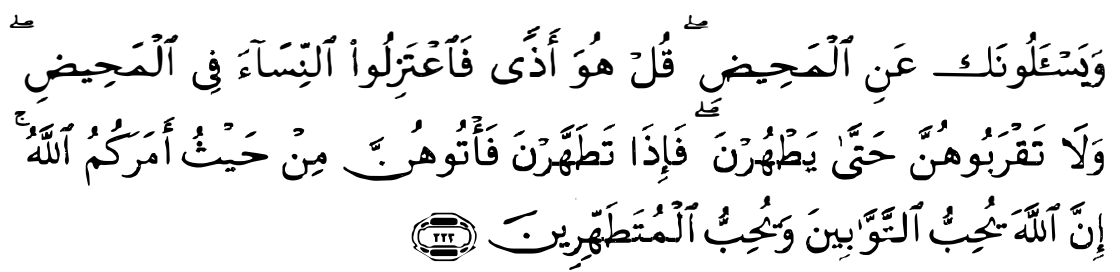

"Mereka bertanya kepadamu tentang haidh. Katakanlah: Haidh itu adalah kotoran." Oleh sebab itu hendaklah kamu menjauhkan diri (tidak menyetubuhi) dari wanita di waktu haidh, dan janganlah kamu mendekati mereka sebelum mereka suci. Apabila mereka telah suci maka campurilah mereka itu di tempat yang diperintahkan Allah kepadamu. Sesungguhnya Allah menyukai orang-orang yang taubat lagi mensucikan diri" (QS. al-Baqarah 222).

Pada satu hari ovulasi dalam suatu siklus, satu atau dua sel telur siap untuk dibuahi. Hidup sel telur tidak lebih dari 24 jam, sedangkan masa hidup sel sperma berbeda-beda. Bila tidak ada lendir yang menunjang kelangsungan hidupnya, sel sperma tidak bisa bertahan hidup lebih dari satu jam atau sekitar itu. Namun dengan adanya lendir cervix yang baik, sel sperma bisa bertahan hidup sampai 2 atau 3 hari, bahkan kadang bisa sampai 4 atau 5 hari lamanya (Patmini, 2004).

Ulul Albab, Vol. 8 No. 2, 2007 


\section{Mencoba Mendapatkan Anak dengan Jenis Kelamin Tertentu Secara Alami}

Metode untuk mendapatkan keturunan anak laki-laki lebih mudah daripada metode untuk mendapatkan anak perempuan. Hubungan badan yang terjadi semakin dekat dengan waktu ovulasi akan mempunyai peluang besar mendapatkan anak laki-laki. Sekresi lendir yang dikeluarkan wanita menjelang ovulasi mendukung untuk kehidupan sperma berjenis Y. Sperma Y dengan ukuran diameter kepala lebih kecil memungkinkan berenang dengan kecepatan tinggi pada kondisi basa, sehingga lebih cepat mencapai sel telur daripada sperma X.

Bahkan hubungan badan yang terjadi beberapa jam sebelum ovulasi, tetapi masih dalam hari itu, sekresilendir yangdikeluarkan masih mendukung kehidupan sperma berjenis Y.

\section{Pentingnya Pengaturan Waktu}

Menentukan waktu ovulasi adalah hal pertama dan paling penting yang harus dilakukan dalam usaha mendapatkan anak yang diinginkan. Pengamatan melalui beberapa siklus bulanan perlu dilakukan sampai yakin kapan waktu ovulasi (Brown, 2005).

Penggunaan metoda pengamatan lendir servik sebagai cara pertama sering digunakan orang untuk menentukan waktu ovulasi. Kemungkinan kita bisa mengalami masa puncak untuk dua hari berturut-turut. Ini adalah alasan kenapa latihan siklus perlu dilakukan beberapa kali untukmenghindari kekeliruan. Meskipun kita memiliki siklus bulanan teratur dianjurkan melakukan latihan siklus minimal 3 kali sehingga lebih yakin. Apabila mempunyai siklus tidak teratur maka dianjurkan untuk melakukan pengetesan berulang dengan metoda pengamatan lendir cervic dikombinasi dengan temperatur basal tubuh atau Body Basal Temperature (BBT) atau yang lain.

Dengan metode BBT, Dr Shettles menyatakan bahwa wanita rata-rata mengalami ovulasi pada saat penurunan dan kenaikan suhu badan. Apabila seorang wanita mengukur suhu badannya pada suatu pagi dan mengamati 
dari grafik siklus sebelumnya bahwa besok pagi suhu bahannya akan meningkat tinggi, maka dianjurkan untuk melakukan hubungan badan dengan suami pada pertengahan waktu penurunan dan peningkatan suhu badan tersebut (Shettles and Rovink, 2006).

Kesempatan yang paling bagus untuk menghasilkan anak dengan jenis kelamin laki-laki adalah dalam waktu 12-24 jam sebelum ovulasi terjadi, sedangkan untuk mendapatkan anak perempuan 2-4 hari sebelum perkiraan waktu ovulasi karena sperma jenis X lebih kuat dan lebih bertahan lama dalam posisi menunggu kedatangan sel telur.

\section{Faktor Suhu}

Menghindari pemakaian celana dalam yang ketat dan pakaian ketat yang lain penting untuk menjaga suhu testis yang ideal. Pemakaian celana ketat akan berpengaruh terhadap kenaikan suhu dalam testis (penghasil sperma), yang berakibat berkurangnya jumlah sperma. Kenaikan suhu dalam testis akan membunuh kedua jenis sperma, tetapi sperma $Y$ akan mati duluan karena lebih sensitif terhadap berbagai tekanan (Shettles and Rovink, 2006).

Selain tekananpanas, faktor lain yang bisa menurunkanjumlah sperma adalah penyakit yang berlarut-larut seperti flu, penggunaan obat-obatan dalam jangka lama baik yang beresep maupun tidak dan bahan kimia yang mengandung racun.

\section{Faktor Alkalin dan Orgasme}

Lingkungan kimia organ reproduksi wanita sangat penting dalam pemilihan jenis kelamin. Kebanyakan wanita mengalami perubahan lingkungan yang lebih beralkalin (basa) dan lebih mau menerima sperma ketika mendekati ovulasi. Tindakan alami yang bisa dilakukan untuk mempertinggi kondisi basa dan daya tembus servical mucus adalah orgasme wanita. Ibu yang menginginkan anak laki-laki harus mencoba untuk mengalami orgasme selama berhubungan badan sebelum ayah mengalami orgasme. Orgasme

Ulul Albab, Vol. 8 No. 2, 2007 
wanita biasanya meningkatkan jumlah sekresi alkalin alami sehingga membantu mengantarkan sperma ke arah servik sedangkan apabila menginginkan anak perempuan sebaiknya si ibu menghindari terjadinya orgasme (Shettles and Rovink, 2006).

Diatas adalah beberapa metode alami untuk mendapatkan anak sesuai dengan jenis kelamin yang diharapkan. Tetapi yang terpenting dari semua itu bahwa para orang tua yang ingin menjadi hamil bukan karena mereka menginginkan seorang anak dengan jenis kelamin yang diinginkan tetapi karena mereka ingin memiliki dan menyayangi anak-anak dengan jenis kelamin apa saja.

Manusia sekedar berusaha dengan cara yang baik dan dihalalkan dalam agama, tetapi yang menentukan hasilnya adalah Allah. Seperti termaktub dalam al-Qur'an Surat asy-Syura ayat 49-50 yaitu:

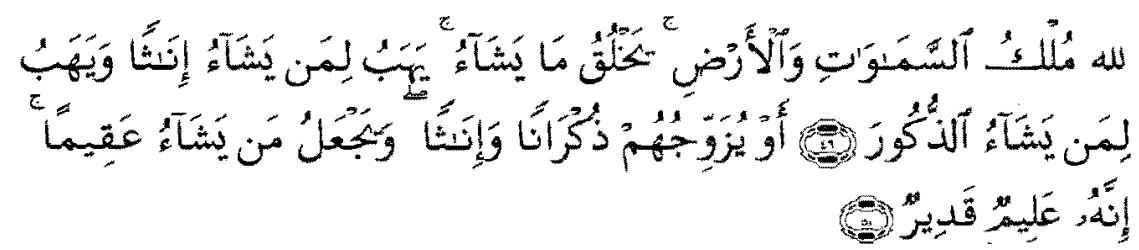

"Kepunyaan Allahlah kerajaan langit dan bumi. Dia menciptakan apa yang dia kehendaki. Dia memberikan anak-anak perempuan kepada siapa yang Dia kehendaki dan memberikan anak laki-laki kepada siapa yang Dia kehendaki, atau Dia menganugrahkan kedua jenis laki-laki dan perempuan (kepada siapa yang dikehendakiNya), dan menjadikan mandul kepada siapa yang dikehendaki. Sesungguhnya Dia maha Mengetahui dan Maha Kuasa."

Dan bahwa Allah Maha mengetahui apa-apa yang ada di dunia ini termasuk seorang wanita mengandung atau tidak, termasuk jenis kelaminnya bayi yang dikandung, wanita melahirkan. Tidak ada satu pun perkara yang luput dari penglihatanNya. Seperti disebutkan dalam al-Qur'an surat Faathir ayat 11.

Ulul Albab, Vol. 8 No. 2, 2007 


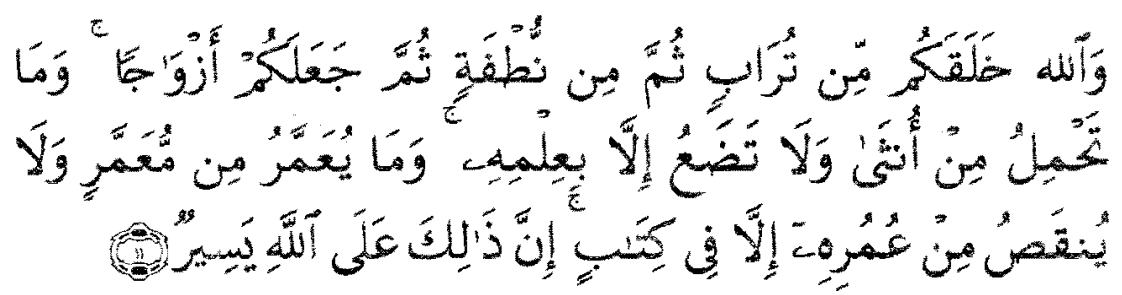

"Dan Allah menciptakan kamu dari tanah Kemudian dari air mani, Kemudian dia menjadikan kamu berpasangan (laki-laki dan perempuan). dan tidak ada seorang perempuan pun mengandung dan tidak (pula) melahirkan melainkan dengan sepengetahuan-Nya. dan sekali-kali tidak dipanjangkan umur seorang yang berumur panjang dan tidak pula dikurangi umurnya, melainkan (sudah ditetapkan) dalam Kitab (Lauh mahfuzh). Sesungguhnya yang demikian itu bagi Allah adalah mudah."

\section{Kesimpulan}

Setiap melihat, menyaksikan dan merenung tentang ciptaan Allah baik alam semesta, proses penciptaan manusia sendiri dan fenomena alam yang lain akan menyadarkan kita bahwa di balik itu semua ada tanda-tanda kebesaran dan kekuasaan Allah. Seperti disebutkan. dalam al-Qur'an Surat al-Ankabut; 44 :

"Allah menciptakan langit dan bumi dengan hak [tidakpercuma/penuh hikmah]. Sesungguhnya pada yang demikian itu terdapat tanda-tanda kekuasaan Allah bagi orang-orang mukmin."

Dari pembahasan yang telah diuraikan dapat disimpulkan beberapa hal sebagai berikut: pertama, komponen air mani yang berperan dalam penciptaan manusia adalah sel spermatozoa. Kedua, jenis spermatozoa lakilaki yang menentukan jenis kelamin bayi yang dilahirkan. Ketiga kondisi asam basa saluran reproduksi wanita mempengaruhi jenis kelamin bayi yang dilahirkan.

Ulul Albab, Vol. 8 No. 2, 2007 


\section{DAFTAR PUSTAKA}

Bucaille, M. 1979. Bibel, Qur'an dan Sains Modern. Alih Bahasa Mohammad Rasyidi. Penerbit Bulan Bintang.

Departemen Agama Repuplik Indonesia. 2005. Al-Qur'an dan Terjemahannya.

Infertility Treathments and Procedure. www3. fertilethoughts.com/forums/ $\mathrm{v}$

JB, Brown. 2005. Pituitary and Ovarian Hormones of a Womans Reproductive Cycle. Obstetrics and Gynaecology. University of Melbourne. Australia.

Naufal, AR. 1987. Al-Qur'an dan Sains Modem. Bandung: Penerbit Husaini.

Patmini, E. 2004. Tips Bagaimana Menentukan Masa Subur. Natural Family Planning.

Purwaningsih, E. 1997. Kelenjar Assesori dan Peranannya Dalam Proses Reproduksi Pria. Jurnal Kedokteran Yarsi edisi Jan. Vol. 5 No. 1. Yarsi University School of Medicine. Jakarta. P: 82-91

Sadler, TW. 1997. Embriologi Kedokteran. Langman. Jakarta: EGC.

Shettles, MD. and Røvink. DM. 2006. Bagaimana Memilih Jenis Kelamin Bayi Anda. Alih Hahasa: Eni. Pustaka Pohon Bodi.

Suhadi, K. 1978. Spernatozoa. Perkumpulan Andrologi Indonesia. Surabaya Terjemah Irsyadul Ibad. Petunjuk Manusia Ke Jalan Yang Benar. Mutiara Ilmu Surabaya.

Yanagimachi, R. 1994. Mammalian Fertilization. In The Physiology Of Reproductive Vol. 1. ed By Knobil E, Neill JD. The Physiology Of Reproduction. Raven Press, Ltd. New york. Chapter 5 : 135 - 185. Yahya, H. 2006. Pengetahuan Al-Qur'an. Harun Yahya Internasional. . Setetes Mani. Harun Yahya Internasional. . 2006. Campuran Dalam Air Mani. Harun Yahya Internasional.

Yatim, W. 1984. Embriologi. Penerbit Tarsito. Bandung. - 1990. Histologi. Biologi Modern. Penerbit Tarsito. Bandung. . 1987. Biologi Sel. Biologi Modern. Penerbit Tarsito. Bandung. 